Transactions of the Royal Society of Edinburgh: Earth

Sciences

http://journals.cambridge.org/TRE

Additional services for Transactions of the Royal Society of Edinburgh: Earth Sciences:

Email alerts: $\underline{\text { Click here }}$

Subscriptions: $\underline{\text { Click here }}$

Commercial reprints: $\underline{\text { Click here }}$

Terms of use : $\underline{\text { Click here }}$

Givetian (Middle Devonian) cladoxylopsid 'ferns' from Orkney, northern Scotland

Christopher M. Berry and Jason Hilton

Transactions of the Royal Society of Edinburgh: Earth Sciences / Volume 97 / Issue 01 / March 2006, pp 65 - 73

DOI: 10.1017/S0263593300001401, Published online: 26 July 2007

Link to this article: http://journals.cambridge.org/abstract_S0263593300001401

How to cite this article:

Christopher M. Berry and Jason Hilton (2006). Givetian (Middle Devonian) cladoxylopsid 'ferns' from Orkney, northern Scotland. Transactions of the Royal Society of Edinburgh: Earth Sciences, 97, pp 65-73 doi:10.1017/S0263593300001401

Request Permissions : $\underline{\text { Click here }}$ 


\title{
Givetian (Middle Devonian) cladoxylopsid 'ferns' from Orkney, northern Scotland
}

\author{
Christopher M. Berry and Jason Hilton
}

\begin{abstract}
Two large fossil plants are described from the Givetian (Middle Devonian) Eday Flags, South Ronaldsay, Orkney Isles, northern Scotland. Fossils with branches joined to stems of this age are rare. Each specimen comprises a robust and tapering main trunk from which numerous closely spaced branches arise distally. Although poorly preserved such that generic identifications are not possible, both specimens display the characteristic architecture of the plant order Pseudosporochnales (Cladoxylopsida). The newly discovered specimens demonstrate a variation in size and form that adds further data to the understanding of the ontogeny of these enigmatic plants, complementing recent morphological and anatomical findings. These specimens, in combination with many more fragmentary fossils of the same kind from the Orcadian sedimentary basin, add to our knowledge of the Givetian floras of Britain, and show that large plants with upright stems were present in the Middle Devonian landscape of Scotland.
\end{abstract}

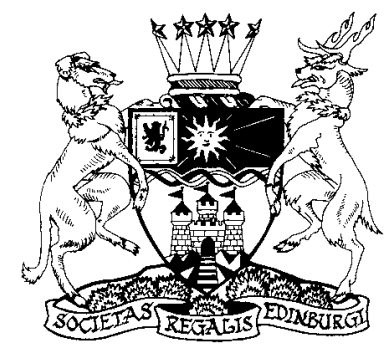

KEY WORDS: Cladoxylopsida, Eday Beds, Eday Flags, Middle Old Red Sandstone, Orcadian basin, Pseudosporochnales.

The Palaeozoic floras of Scotland, amongst the best known globally, include some classic localities that have shaped knowledge of early land plants and terrestrialisation. Foremost in these are the Lower Devonian Rhynie Chert in Aberdeenshire and the Lower Calciferous Sandstone Series in southern Scotland. The Rhynie Chert preserves in immaculate detail the flora and fauna of an in situ hot-spring ecosystem that has provided an unrivalled glimpse into an early terrestrial ecosystem (e.g. Trewin 1994; Kerp et al. 2001). In contrast, the Calciferous Sandstone Series contains exceptionally well preserved plant fossils in volcaniclastic sediment (Long 1975; Scott 1990; Bateman \& Rothwell 1991). However, considerably less is known about the fossil floras of Scotland from the stratigraphic interval between these assemblages; it is apparent that the majority of sites at which fossil plants have been found from this interval include either fragmentary fossil plant remains or poorly preserved specimens (e.g. Salter 1857; Peach 1879; Chaloner 1972). From this kind of evidence it has been difficult to identify, reconstruct and interpret successfully many of the fossil plants previously reported, a fact recognised by the absence of Middle and Upper Devonian whole-plants from Scotland (e.g. Berry \& Fairon-Demaret 2001).

In this paper we document the first semi-complete fossil plants from the Givetian (Middle Devonian) Orcadian Basin of northern Scotland, and use their gross morphology to interpret them as members of an extinct cladoxylopsid group. We further consider them in terms of their mode of growth and architecture, and also consider the distribution of this important plant group during the Middle Devonian.

\section{Locality and geological information}

The fossils described were collected from Herston Taing, South Ronaldsay, Orkney (NGR: ND 414 919; Fig. 1). This previously unrecorded coastal locality exposes the Eday Flags that constitute part of the Givetian (Middle Devonian) Eday Beds (Mykura 1983; Marshall 1996).

The Eday Beds form part of the Middle Old Red Sandstone of the Orcadian basin, NE Scotland. Depositional facies represent an intermontane area, with non-marine lake sedi-

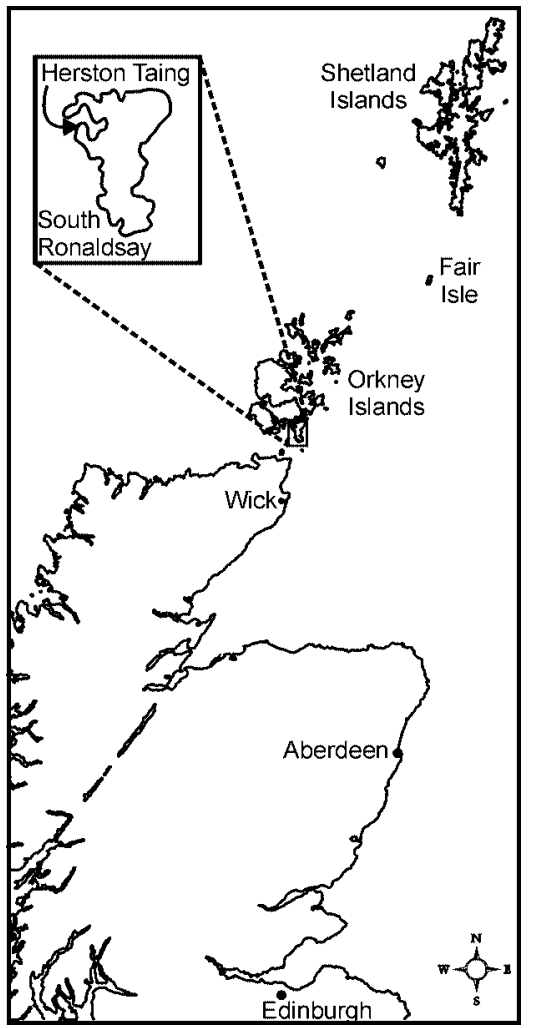

Figure 1 Map of northeastern Scotland showing Orkney Islands, South Ronaldsay and the Herston Taing locality.

ments in the centre of the basin progressing into fluvial sediments draining into the lake (Donovan et al. 1974; Anderton et al. 1992).

In southern Orkney, the Eday Flags attain a maximum thickness of approximately $150 \mathrm{~m}$, thinning northwards to approximately $10 \mathrm{~m}$ towards Eday itself (Donovan et al. 1974; Mykura 1983). The Eday Flags show cyclic deposition. Deep water parts of the cycles are grey laminites that alternate between dolomitised mudstones and fine-grained grey sandstones. Upper parts of the cycles often consist of thick fluvial 


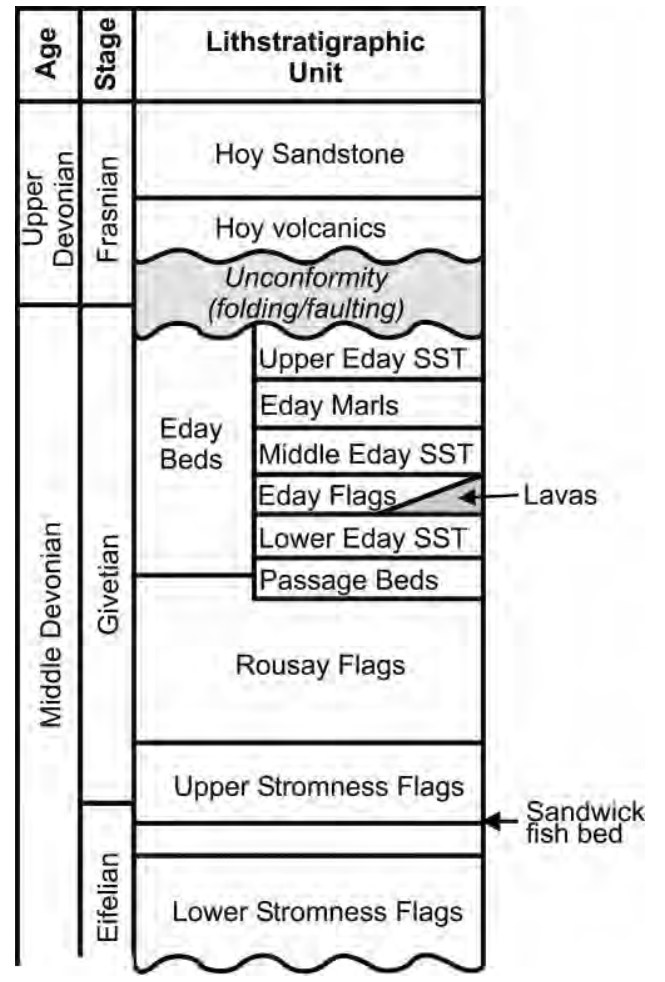

Figure 2 Simplified stratigraphic column of the Old Red Sandstone within the Orcadian Basin, Orkney, showing position of the Eday flags. Diagram modified from Mykura (1983).

phases of red or yellow sandstones, representing in-filled river channels or delta distributaries on the lake floor (Mykura 1983; Marshall 1996). Deep water lacustrine deposits contain abundant fish including Tristichopterus, Pentlandia, Microbrachius and Watersonosteus (Dineley \& Metcalf 1999) as well as rare plant fossils such as those reported in the present paper. The Eday Beds overlie the lacustrine Rousay Flags and mark a change from predominantly lacustarine environments into predominantly fluviatile conditions (Mykura 1983) through the basal Passage Beds (Fig. 2).

\section{Material and methods}

The two specimens described and illustrated in the present paper were collected and prepared for display by Paul de Buisonje and Jan den Blaauwen in the early 1990s. They constitute part of the Buisonje collection at the National Museums of Scotland and are numbered NMSG1995.4.328 and NMSG1995.4.79. We have not examined the counterparts retained in private collections. Both specimens are preserved in a light to medium grey coarse mudstone matrix with some mica flakes. The matrix is extremely hard, which does not facilitate easy preparation or dégagement (Fairon-Demaret et al. 1999). Needles break or are bent before almost any matrix is removed. Vibrotools or other mechanical preparations are likely to damage the fossils themselves as they are coalified compressions with numerous closely spaced cleat fractures along which they readily break up. The appendages and other fine details of plant morphology that normally respond best to the dégagement technique are not preserved in these specimens. As such, the main information they yield is the general arrangement and gross morphology of the plants. In both cases the specimens appear to be partially degraded prior to preservation.

Photography was carried out using a Nikon $35 \mathrm{~mm}$ SLR camera with a $60 \mathrm{~mm}$ macro lens, using low angled illumina- tion and polarising filters to enhance the contrast of the fossils to the matrix and to remove reflections from mica grains.

\section{Results}

Both specimens demonstrate the same overall gross morphology, comprising a main trunk that is robust and tapers distally, from which numerous lateral branches arise in the distal portions of the plant.

\subsection{Large specimen (NMSG.1995.4.328; Figs 3, 5a)}

The maximum dimensions of the largest specimen are $950 \mathrm{~mm}$ high by $650 \mathrm{~mm}$ broad. The left-hand margin of the specimen was truncated along a straight vertical fracture in the rock that fortunately only affected a small part of the fossil. A prominent oblique fracture filled with calcite also runs across the specimen.

Around the distal part of the specimen, a large area of the surface of the rock is covered in a very dense mat of closely adpressed elongate sporangia each up to $1 \mathrm{~mm}$ in length. We could find no evidence to link them to the main fossil. Given the poor preservation of the branches that show evidence of decay and transport, it is unlikely that the sporangial mass and the large plant specimen were organically connected. It is most likely that these sporangia represent a mat of fertile material from another plant that became caught up in the distal branches of the large specimen.

3.1.1. Trunk. The trunk is approximately $650 \mathrm{~mm}$ in length and a maximum of $37 \mathrm{~mm}$ in width in the basal region (Fig. 3). Distally, where branches are present, it is about $23 \mathrm{~mm}$ in diameter, although the branches are so closely inserted and densely adpressed that exact measurement is not possible.

A cleat fracture is present in the approximately $1 \mathrm{~mm}$-thick layer of coalified tissue that makes up the trunk compression. The cleat fracture is almost but not exactly concordant with the stem length and may appear falsely as xylem tissue. However, no anatomical structure is visible at high magnification, the coal fabric having overprinted any stem structures present. Low angle illumination of the stem surface failed to show any type of regular patterning of raised and depressed areas identifiable as branch scars.

The very base of the stem is kinked sharply to the left. We cannot determine if it has been twisted taphonomically or if this represents a genuine morphological feature. We investigated the possibility that the base of the trunk is enlarged or swollen symmetrically by dégaging some of the surrounding matrix. We were unable to uncover any trunk tissues other than those visible in the illustration. The base of the trunk is abruptly truncated by the edge of the slab and so we do not know the actual life height of the trunk and so the measurements given must be taken as a minimum only. We have no evidence of the rooting system.

The margins of the lower part of the trunk are essentially smooth such that enations or any other sort of cellular projections are either not present or not preserved.

3.1.2. Branches. Branches are laterally attached to the top $25 \mathrm{~cm}$ of the trunk only, the proximal two thirds of the visible trunk being devoid of branches. The branches are densely inserted around the trunk, and over 50 are visible on the surface of the fossil. In small areas where as little as $1 \mathrm{~mm}$ of matrix surface has been removed, further compressed branches are visible. Therefore the total number of branches originally attached to the trunk must have been very much higher.

The maximum width of branches at their bases is exceptionally $10 \mathrm{~mm}$ but a large number are $8 \mathrm{~mm}$ in width. A few are 


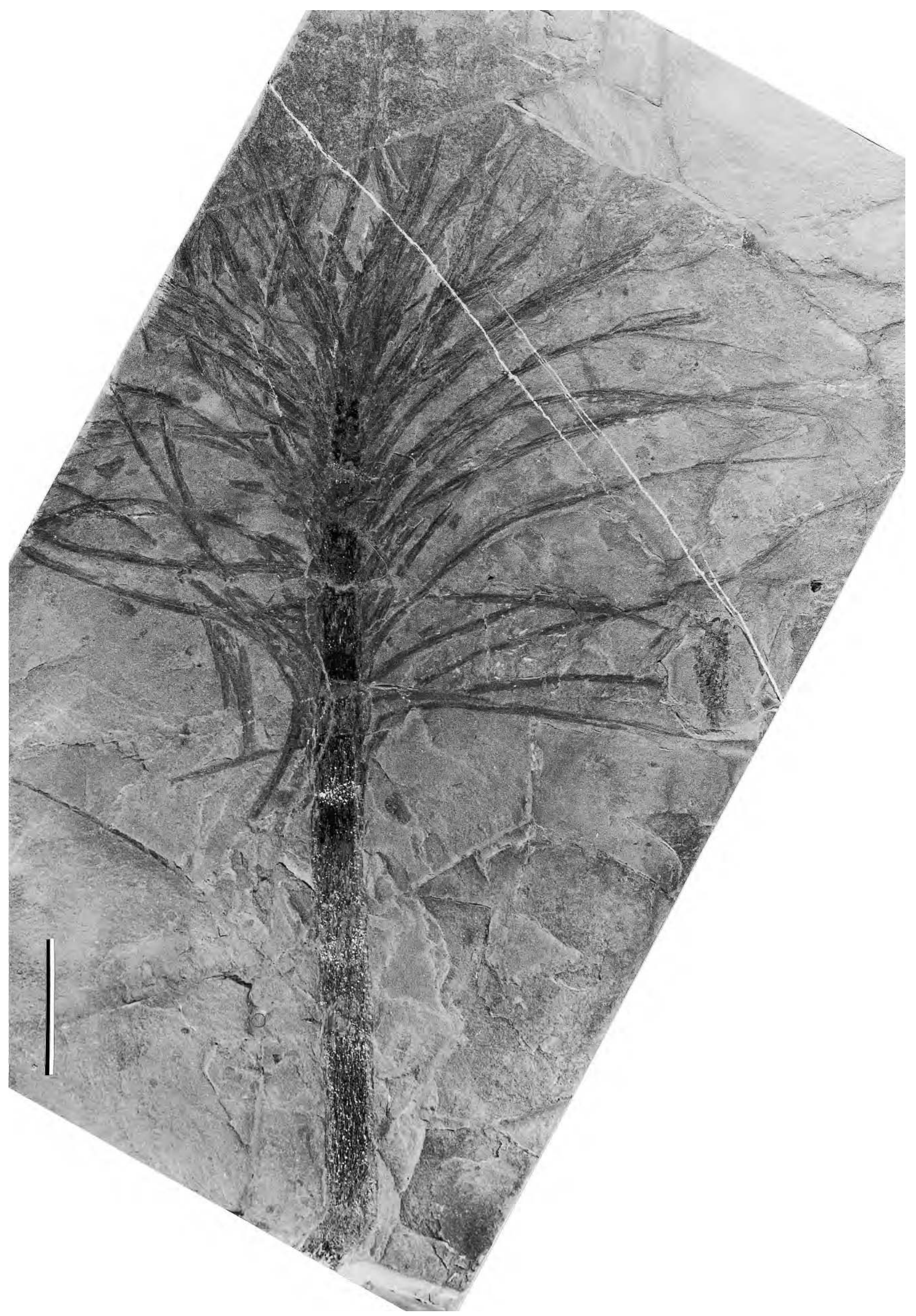

Figure 3 The larger of two cladoxylopsid fossils from Herston Taing, South Ronaldsay, Orkney. NMSG1995.4.328. Scale bar $=100 \mathrm{~mm}$. 
much narrower at about $3.5 \mathrm{~mm}$, and these are found in the same areas of the trunk as the wider examples. Therefore it is likely that the branches were not terete but actually more oval in transverse section proximally, the visible preserved width therefore being influenced by orientation. Branches are so tightly adpressed that many run alongside or on top of others and therefore look falsely wide.

The maximum preserved length of branches is $400 \mathrm{~mm}$, from a base of $8 \mathrm{~mm}$ width narrowing to about $5 \mathrm{~mm}$ at mid-length. Branches are acutely inserted, about 25 degrees from the vertical, towards the top of the trunk but less acutely towards the bottom of the branch-bearing zone.

The ends of the branches are badly preserved. The illustrations are misleading in that, towards the apices, narrow laterals are seen to be given off acutely (e.g. Fig. 5a). Close inspection strongly suggests that the laterals are stray pieces of brokendown vascular tissues. They demonstrate no branching themselves. In other cases wider laterals appear to be emitted from the branches, but these are most often demonstrated to be continuations of other branches partially hidden by matrix, or formed by the fraying of the distal part of the branch. We are unable to demonstrate any convincing ramification of branches.

\subsection{Small specimen (NMSG.1995.4.79; Figs 4, 5b)}

This specimen is preserved on a slab very close to a specimen of the fish Tristichopterus alatus Egerton.

3.2.1. Trunk. The trunk is $330 \mathrm{~mm}$ long, and is abruptly truncated at the base. It has a diameter of $21 \mathrm{~mm}$ at the base and $19 \mathrm{~mm}$ in the middle. Just above the middle there is an obvious bottle-shaped constriction of the trunk, the remaining third of the preserved trunk being between $9-10 \mathrm{~mm}$ in width. In this narrower region many branches are inserted acutely at about 30 degrees from the upright. About 16 branches are seen in various states of preservation, the most complete being at the very top of the visible trunk. The upper termination of the trunk is abrupt, but branches are seen to lie on the surface of the matrix pointing in the same orientation as the trunk. It is therefore likely that the actual apex of the plant lies on the counterpart.

Below the distal-most $20 \mathrm{~mm}$ of the trunk there are fewer branches visible. One pair of branches emerges from the right margin, and below that, towards the top of the constriction in the trunk, two short $20 \mathrm{~mm}$ bases of branches are visible on opposite sides of the trunk. We believe that the trunk has been badly damaged in post mortem transport, breaking the bottom of the trunk and stripping many of the branches from the middle and upper region of the trunk. There is no evidence for attached branches below the level of constriction.

3.2.2. Branches. The branches are all incomplete and appear longitudinally striated (Fig. 5b). Those on the left of the top of the trunk descend into the matrix. Those to the right each terminate abruptly. They range from 1.8 to $2.3 \mathrm{~mm}$ in diameter, and any that appear to be wider on closer examination can be seen to be the product of two closely adpressed branches. Any apparent branching is most likely caused by the separation of such overlying branches. The distal tips of the branches to the uppermost right-hand side of the specimen are about $2 \mathrm{~mm}$ in diameter and appear to dichotomise into two short terminal segments each about $1 \mathrm{~mm}$ in diameter. However, in view of the poor preservation of this specimen, it is equally likely that the end of this branch is frayed. Although inserted acutely, the branches are abaxially recurved distally.

\section{Affinities of the plants \\ 4.1. Higher level groups}

There are three principal groups of well known, non-lycopsid vascular plants in the Middle Devonian of Europe, Scandinavia and the Americas (Berry \& Fairon-Demaret 2001). These are progymnosperms, iridopterids and cladoxylopsids.

Concepts of morphology and anatomy of Middle Devonian progymnosperms have been developed since the 1970s and suggest the presence of two lineages, aneurophytalean and archaeopteridalean progymnosperms (Beck \& Wight 1988). Aneurophytaleans such as Rellimia, Tetraxylopteris and Aneurophyton have stiff, regularly branched axial systems; alternate and decussate branching patterns prevail in Tetraxylopteris and helical branching is known in other taxa (Beck \& Wight 1988; Dannenhoffer \& Bonamo 2003). There is a very well-defined hierarchical system of orders of branching, with generally widely spaced insertion of laterals. Typically branches are not very much smaller in diameter than the trunk they are carried on, and higher order (i.e. more distal) branches are also relatively large. Some of these features would be expected to be observed in branches of the sizes observed in our specimens if they were progymnosperm, especially the bases at least of second order branches. In terms of anatomy, trunk and branches contain a three or four-ribbed xylem column which leaves a strongly striated one, two or threeribbed aspect to the compression fossils. In the present material, striations are observed in the branches, but these are more numerous suggesting a vascular system with many more ribs, or one that was strongly dissected and therefore unlike aneurophytaleans (e.g. Beck \& Wight 1988).

A number of plant architectures have been suggested for archaeopteridalean progymnosperms. The earliest reconstructions of Archaeopteris considered it to be fern-like (e.g. Seward 1933; see Chaloner 1999). However, the discovery of organic connection between the stem (Callixylon) and the foliage (Archaeopteris) by Beck (1960a) led to a markedly different view reconstructing the plant as conifer-like (Beck 1960b). This represents a plant with a main stem with pseudomonopodial branching in its lateral systems, from which Beck and Wight (1988) suggested that the 'crown of the plant was probably more diffusely branched than previously thought'. This organisation is distinct from that displayed in the specimens described in the present paper, and in particular relative sizes and positions of the lateral branches produced by the main stem distinguish the two kinds of plants. Chaloner (1999), on the other hand, demonstrated another specimen of Archaeopteris/ Callixylon with an architecture differing from Beck's (1960b) model, having a 'more fern-like aspect, with prominent lateral branches and a less extended monopodial axis' (Chaloner 1999, p. 72). The architecture suggested by Chaloner (1999) is also distinct from the specimens we described herein, again most noticeably in the relative sizes and organisation of the lateral branches in relation to the main stem. A further archaeopteridalean, Eddya sullivansis Beck, differs from both of these Archaeopteris/Callixylon architectures and is a small plant (possibly juvenile) which bears small, fan shaped leaves directly on its upright stem (Beck 1967). This is again clearly distinct from the gross morphology of the plants we describe, showing that the plants from Orkney are not archaeopteridalean progymnosperms.

Iridopteridalean plants have recently become better understood from a morphological perspective (Berry \& Edwards 1996; Berry \& Stein 2000). They have a branching pattern that is whorled. In each whorl a trace emerges from each rib or alternate ribs of the ribbed vascular strand and may supply a 


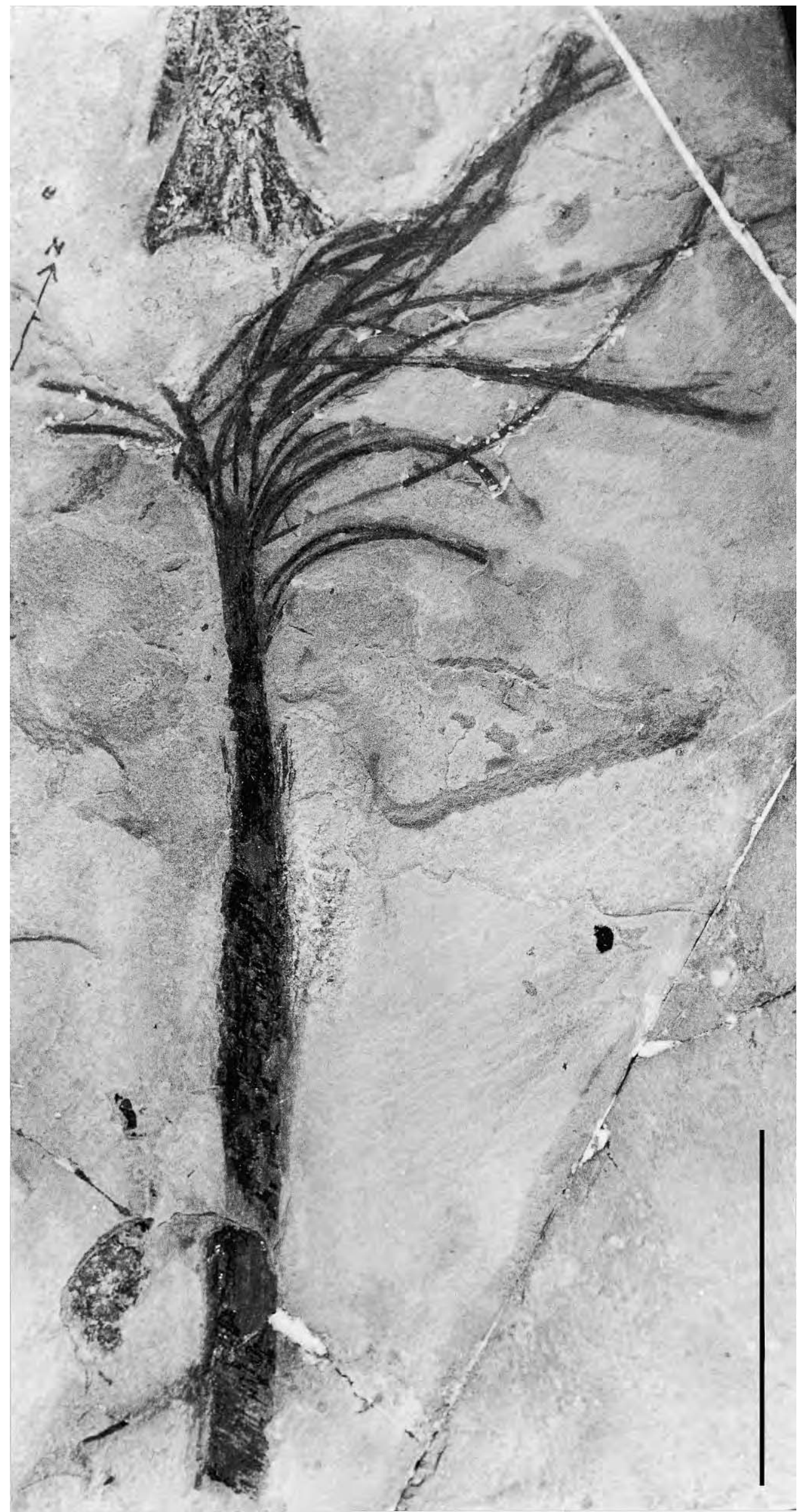

Figure 4 The smaller of two cladoxylopsid fossils from Herston Taing, South Ronaldsay, Orkney. NMSG1995.4.79. Scale bar $=100 \mathrm{~mm}$. 

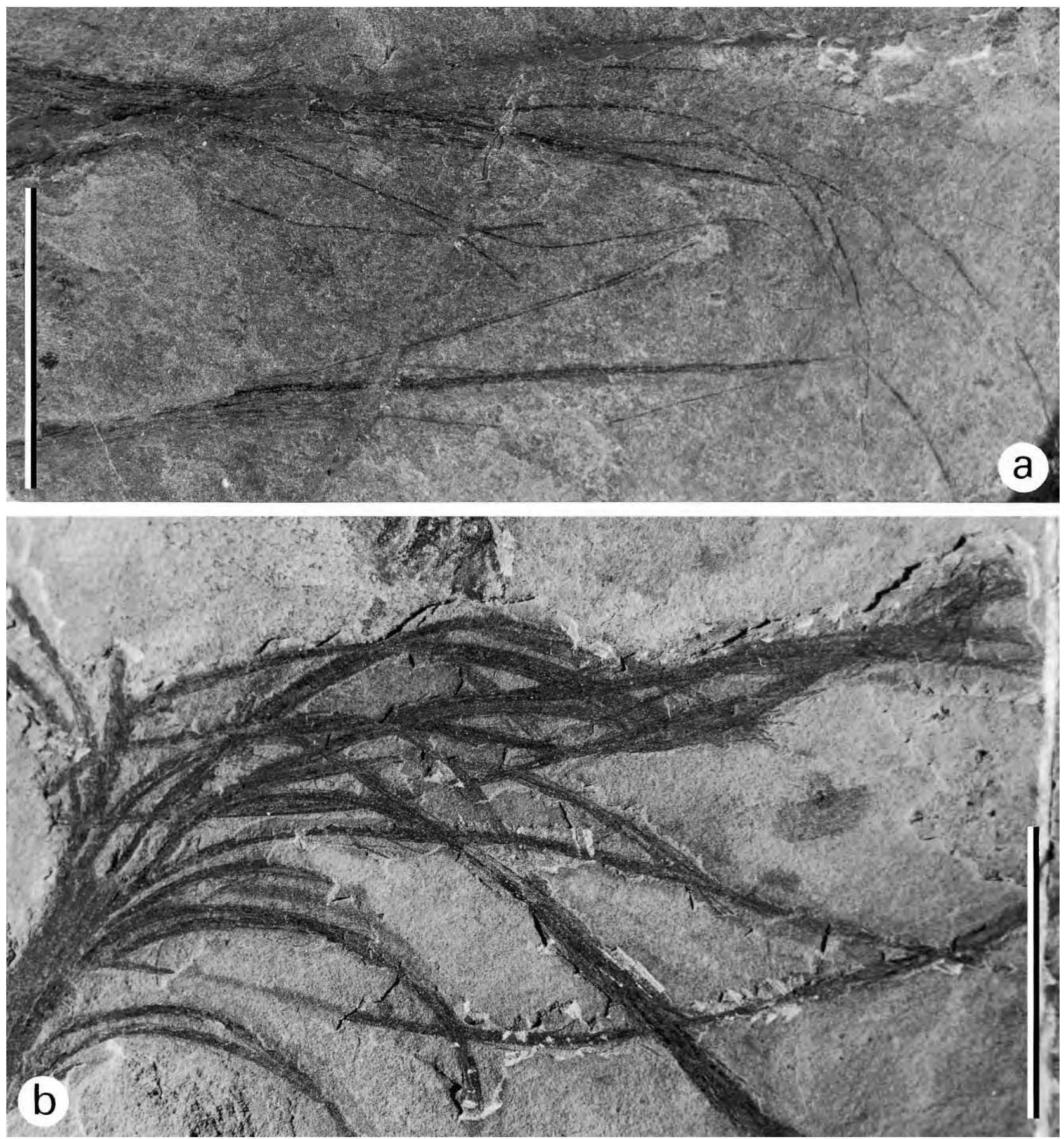

Figure 5 Details of the lateral branches of the two cladoxylopsid specimens: (a) Enlargement of the frayed lateral branches from Figure 3. Scale bar $=50 \mathrm{~mm}$ (NMSG1995.4.328). (b) Crown and wispy lateral branches from the smaller specimen, enlarged from Figure 4 showing apparent lineation within the lateral branches. Scale bar=50 mm (NMSG1995.4.79).

dichotomous appendage or a higher order branch. Each order of branching reiterates this pattern. This pattern of branching is not found in either the lateral branches or the trunk of the specimens described in this paper, discounting the newly described specimens from being iridopteridalean.

At present, within cladoxylopsids (Emsian-Early Carboniferous), the Pseudosporochnales (Eifelian-Frasnian) are the only well defined group. Pseudosporochnales includes the genera Pseudosporochnus Potonie et Bernard, Calamophyton Kräusel et Weyland, Lorophyton Fairon-Demaret et Li, and Wattieza Stockmans, all known primarily from compressions. Characteristics of the predominantly Middle Devonian Pseudosporochnales include an upright trunk, densely inserted braches which have digitate ramification in larger plants, small largely dichotomous appendages inserted on the branches without geometrical regularity, and nests of sclereids in the cortex. There are several anatomically or morphologically preserved plant axes which, although having the highly dissected stele characteristic of cladoxylopsids, are demonstrably not members of Pseudosporochnales based on their morphology, nor on their morphology inferred from their anatomy. Iridopteridales in our current understanding are not members of the cladoxylopsids.

The architecture of two members of Middle Devonian Pseudosporochnales have recently been established, based on the characteristics of the whole plant Lorophyton by FaironDemaret and $\mathrm{Li}$ (1993) and reconstruction of Pseudosporochnus by Berry and Fairon-Demaret $(1997,2002)$. These 
plants consist of a central trunk with densely inserted lateral branches that in larger examples are digitately branched but in smaller specimens are unbranched. The pattern of insertion of these branches is dense, essentially in vertical ranks, with some suggestion of horizontal whorls and alternation (Berry \& Fairon-Demaret 2002). Branches may be considerably smaller than the trunks to which they are attached, and bear relatively small appendages. It is to this order that our plants show most similarity and we will make further comparisons below.

\subsection{Comparison with Middle Devonian Pseudosporochnales}

Generic determination of Pseudosporochnales is most commonly on the basis of the morphology of the often complex lateral sterile and fertile appendages (Berry 2000). The new specimens lack appendages on their lateral branches. Such organs are delicate and of small diameter in comparison with the branches on which they are borne (e.g. Berry 2000; Berry \& Fairon-Demaret 1997, 2002), and are likely to have been lost during transport of the specimens into the depositional basin. Identification of the plant at the generic level is therefore impossible, as the trunk/branch morphology displayed is otherwise believed typical for the order Pseudosporochnales as a whole (Berry \& Fairon-Demaret 2002). We therefore will make comparison with other individual specimens of such plants.

The most complete compression fossil of a pseudosporochnalean cladoxylopsid is the single trunk specimen of Lorophyton goense, with attached undivided branches, from the Middle Devonian (late Eifelian) of Belgium (FaironDemaret \& Li 1993). This specimen is interpreted as a juvenile because isolated ramified branch material of larger diameter and but with identical appendage morphology has been found at the same locality (Fairon-Demeret \& Li 1993; Berry \& Fairon-Demaret 2002). The trunk is a little smaller than that found in our smaller specimen, some $15 \mathrm{~mm}$ in diameter and $200 \mathrm{~mm}$ in length. It bears more than 30 acutely inserted crowded branches that are undivided but which bear small dichotomising lateral appendages. The branches are $4 \mathrm{~mm}$ wide at the base and are up to $120 \mathrm{~mm}$ long; the ratio of width of the branches to appendages is c. 10:3. Larger isolated branches are branched dichotomously. Branches are most complete around the apex. Towards the lower part of the trunk they are broken to only about $20 \mathrm{~mm}$ length and near the base there are no branches visible at all. At the base of the trunk there is a slightly enlarged base, slightly offset to one side and a dense mat of roots still surrounded by some of the original sandy soil in which the plant was growing before transport. The juvenile Lorophyton specimen therefore bears a high degree of similarity to our small specimen. Differences include the lack of appendages, lack of basal region, and flexure of the branches, each undoubtedly attributable to the degree of abrasion and decay related to the transport of our specimen.

Schweitzer $(1972,1973)$ described a suite of specimens from Lindlar, Germany, including lots of trunk material under the names Calamophyton and Hyenia. However, the species described were subsequently united within a single species, Calamophyton primaevum by Fairon-Demaret and Berry (2000). Most of the trunks of C. primaevum are of comparable size to our smaller specimen $(14 \mathrm{~mm} \times 300 \mathrm{~mm})$ and include the basal region and roots. They show acutely inserted branches that are more complete distally and broken off close to the trunk proximally, but are not ramified. One larger trunk, preserved only at the base, is more than $100 \mathrm{~mm}$ in diameter. This is the size of trunk that may have borne larger branches of up to $30 \mathrm{~mm}$ diameter with close anisodichotomous branching giving the digitate or more complex ramification patterns characteristic of the genus (e.g. Leclercq \& Andrews 1960). These branches bore many small and fairly robust dichotomous appendages. Calamophyton was reconstructed by Schweitzer (1973) as a small tree, with a central trunk and lateral branches that became more complexly ramified as the trunk grew higher. Schweitzer (1973) only included a few, sparsely inserted branches in his reconstruction.

Semi-complete trunk specimens are unknown for Pseudosporochnus nodosus from Belgium. However, $60 \mathrm{~mm}$-diameter trunk fragments have recently been recognised to demonstrate branch scars to which characteristic lateral digitate branches were interpreted to be originally attached (Berry \& FaironDemaret 2002). The new facts prompted a revised reconstruction of Pseudosporochnus that now appears very similar to the architecture of the larger specimen of this study apart from the fact that the branches have digitate ramification in the larger Pseudosporochnus.

\section{Discussion}

Our assignment of the specimens described in the present paper to the cladoxylopsid order Pseudoporochnales is based on the observed branching patterns of the trunk, as this is the only informative character observed in the material. However, we believe that the assignment is sound because no other Middle Devonian plants have such a type of habit. We also believe that the specimens we describe here both belong to the same species of plant because they were found in the same unit close together, and have the same overall morphology.

The fossils can be most easily interpreted as both representing the same part of the plant - the almost complete trunk and branches - but at different stages of growth. Ontogenetic profiles of plant fossils are perhaps best explored by using anatomical features, largely concerning secondary tissues and sometimes growth rings, in well preserved permineralised specimens. Compression fossils are often too fragmentary to convincingly demonstrate ontogeny. However, in these two stem and branch specimens we are probably seeing two snapshots in the life cycle of a single species of plant.

Although recent work has cleared up some of the confusion about the anatomy and morphology of Middle Devonian pseudosporochnalean cladoxylopsids (Stein \& Hueber 1989; Berry \& Fairon-Demaret 1997, 2002; Fairon-Demaret \& Berry 2000; Berry 2000), one fundamental mystery is the behaviour of the stems during ontogeny. Whereas some authors (e.g. Soria et al. 2001) consider that there was little potential for secondary growth in the trunks of such plants (their argument apparently being based on the model of Pietzschia, a nonpseudosporochnalean cladoxylopsid) others (e.g. Berry \& Fairon-Demaret 2002) believe that suites of compression fossils demonstrate that secondary growth must have occurred. Calamophyton suggests a growth pattern which had increasingly large branches inserted as the trunk grew taller (Schweitzer 1973) and as, presumably, the trunk grew wider. Lorophyton similarly displays larger, dichotomised branches isolated in the sediment that contrast with the narrow undivided branches that are found on the small, presumably juvenile specimen (Fairon-Demaret \& Li 1993; Berry \& Fairon-Demaret 2002). The Orkney cladoxylopsid now demonstrates a small specimen, with a short trunk and narrow branches, and a taller specimen with a thicker trunk and wider branches. Short whole plant pseudosporochnaleans (i.e. juveniles) are narrow in diameter and not broad as in, for example, palms or arborescent lycopsids that show relatively little secondary expansion after considerable vertical growth. These facts are best explained by a plant with a trunk that increases 
in girth (secondary growth) as the plant grows taller and emits larger branches. We are left with the question as to how the secondary growth is achieved in Pseudosporochnales (Berry \& Fairon-Demaret 2002), and to answer this will require the study of anatomically preserved trunk material, as is currently in progress (Berry, in progress).

Though anatomically and morphologically distinct from members of Pseudosporochnales, the Upper Devonian (Famennian) cladoxylalean Polypetalophyton wufengensis Hilton, Geng et Kenrick possesses woody tissues in its lateral branch system (Hilton et al. 2003). In this species the vascular system comprises numerous (typically $8-12$ ) primary vascular segments each of which consists of tracheids and parenchyma surrounded by wood comprising radially aligned tracheids with ray-like slits. Hilton et al. (2003) considered the woody tissues to be radially aligned metaxylem rather than secondary xylem. Although only the lateral branch systems of Polypetalophyton is known, its organisation suggests the presence of similar woody tissues in the stem. Polypetalophyton suggests that at least some cladoxylopsids were able to produce wood, but shows this was distinct from that known in lignophytes (progymnosperms and seed plants) with secondary xylem production and a bifacial vascular cambium (e.g. Rothwell \& Serbet 1994).

The Orkney specimens both have branches which are undivided as far as can be determined, and, comparing the material to Calamophyton and Lorophyton, this suggests that both specimens are likely to be juvenile, albeit it with the larger specimen presumably slightly older than the smaller specimen. We have not yet visited the locality to collect specifically for plant fossils, but the occurrence of typically digitate pseudosporochnalean branches might be expected if the plants continued to grow in both height and girth. Such branches are believed to have been regularly abscised from Pseudosporochnus and other pseudosporochnaleans during upward growth (Berry \& Fairon-Demaret 2002) and several hundred such branches might have been shed in the life cycle of a large example. This would explain why cladoxylopsid branches are very common at many Middle Devonian sites where abundant plant assemblages are found. Digitate branches are found in the Middle Devonian Orcadian Basin of Scotland, both on the mainland and on the northern isles, but are generally fragmentary and lack appendages so cannot be positively identified to any genus. These often remain unpublished or are discarded when found. One published record is of 'Pseudosporochnus' sp. by Lang (1927) from near Stromness (about $30 \mathrm{~km}$ northwest of the Herston Taing site), a single digitately-branched axis almost certainly derived from the branch of a larger individual of our plant or a related pseudosporochnalean. The specimen is $350 \mathrm{~mm}$ long, with a rounded base some $40 \mathrm{~mm}$ wide narrowing to $25 \mathrm{~mm}$ wide just below the branching point. Each of the four diverging daughter axes are $10 \mathrm{~mm}$ in diameter and are preserved only over $50 \mathrm{~mm}$ before being broken. Fossil plant remains such as this are typical of the Middle Devonian deposits in North and South America and Europe. The locality of Lang's specimen is from the Shandwick Fish Bed or Upper Stromness Flags and may be uppermost Eifelian or basal Givetian in age (Mykura 1983). This occurrence, in combination with the specimens described in the present paper, and also the presence of numerous fragmentary parts of cladoxylopsids in existing museum collections, demonstrates that this plant group with their characteristic large upright stems and dense lateral branch organisation, was common and abundant in the Middle Devonian floras of Scotland. Additional specimens should now be sought either from more proximal sedimentary settings in which decay was less pronounced, or anatomy is preserved. Either of these are likely to present significant advances in our existing knowledge of British Middle Devonian floras, and will go further in filling the gaps between recognised fossil plant bearing lagerstätten.

\section{Conclusion}

Two spectacular plant fossil specimens showing trunk and attached lateral branches from the Middle Devonian of the Orkney Islands have a growth habit most similar to the emerging concept of Middle Devonian specimens of the extinct plant order Pseudosporochnales (Cladoxylopsida). These represent the first attached stem and branch members of this group recognised from the British Isles. They add further data to knowledge of the ontogeny of these enigmatic plants, and to our understanding of the appearance of the Middle Devonian landscape of Scotland.

\section{Acknowledgements}

We gratefully acknowledge the time and effort in collecting and preparing the fossils reported here by Paul de Buisonje and Jan den Blaauwen, providing the authors with this unique opportunity to study pseudosporochnalean plants. Dr L. Anderson and Dr R. L. Paton (National Museums of Scotland) are thanked for assisting the various parts of this investigation and for discussing the fossil-bearing sequences of the Orcadian basin, and D. Mitchell (National Museums of Scotland) for helping prepare Figure 1. J. E. A. Marshall is thanked for discussion on stratigraphy and correlation of the Eday Flags. M. Fairon-Demaret and W. Stein are thanked for their helpful reviews.

\section{References}

Anderton, R., Bridges, P. H., Leeder, M. R. \& Sellwood, B. W. 1992. A dynamic stratigraphy of the British Isle, a study in crustal evolution. London: Chapman and Hall.

Bateman, R. M. \& Rothwell, G. W. 1991. A reappraisal of the Dinantian floras at Oxroad bay, East Lothian, Scotland. 1. Floristics and whole plant concepts. Transactions of the Royal Society of Edinburgh: Earth Sciences 81 (for 1990), 127-59.

Beck, C. B. 1960a. Connection between Archaeopteris and Callixylon. Science 131, 1524-5.

Beck, C. B. 1960b. The identity of Archaeopteris and Callixylon. Britonnia 12, 351-68.

Beck, C. B. 1967. Eddya sullivanensis, gen. et sp. nov., a plant of gymnospermic morphology from the Upper Devonian of New York State. Palaeontographica Abh. B 121, 1-22.

Beck, C. B. \& Wight, D. C. 1988. Progymnosperms. In Beck, C. B. (ed.) The origin and evolution of gymnosperms. New York: Columbia University Press.

Berry, C. M. 2000. A reconsideration of Wattieza Stockmans (here attributed to Cladoxylopsida) based on a new species from the Devonian of Venezuela. Review of Palaeobotany and Palynology 112, $125-46$.

Berry, C. M. \& Edwards, D. 1996. Anapaulia moodyi gen. et sp. nov.: a probable iridopteridalean compression fossil from the Devonian of western Venezuela. Review of Palaeobotany and Palynology 93, $127-45$.

Berry, C. M. \& Fairon-Demaret, M. 1997. A reinvestigation of the cladoxylopsid Pseudosporochnus nodosus Leclercq et Banks from the Middle Devonian of Goé, Belgium. International Journal of Plant Sciences 158, 350-72.

Berry, C. M. \& Fairon-Demaret, M. 2001. The Middle Devonian Flora revisited. In Gensel, P. \& Edwards, D. (eds) Plants invade the land: evolutionary and environmental perspectives, 120-39. New York: Columbia University Press.

Berry, C. M. \& Fairon-Demaret, M. 2002. The architecture of Pseudosprochnus nodosus Leclercq et Banks: a Middle Devonian Cladoxylopsid from Belgium. International Journal of Plant Sciences 163, 699-713. 
Berry, C. M. \& Stein, W. E. 2000. A New Iridopteridalean from the Devonian of Venezuela. International Journal of Plant Sciences 161, 807-27.

Chaloner, W. G. 1972. Devonian plants from Fair Isle, Scotland. Review of Palaeobotany and Palynology 14, 49-61.

Chaloner, W. G. 1999. The architecture of the Archaeopteris/ Callixylon tree. In Keurman, M. H. \& Hemsley, A. R. (eds) The evolution of plant architecture, 65-74. Kew: Royal Botanic Gardens, Kew.

Dannenhoffer, J. M. \& Bonamo, P. M. 2003. The wood of Rellimia from the Middle Devonian of New York. International Journal of Plant Sciences 164, 429-41.

Donovan, R. N., Foster, R. J. \& Westoll, T. S. 1976. A stratigraphical revision of the Old Red Sandstone of North-eastern Caithness. Transactions of the Royal Society of Edinburgh: Earth Sciences 69. 167-201.

Dineley, D. L. \& Metcalf, S. J. 1999. Fossil fishes of Great Britain. Geological Conservation Review Series, Joint Nature Conservation Committee. 1-675.

Fairon-Demaret, M., Hilton, J. \& Berry, C. M. 1999. Surface preparation of macrofossils - dégagament. In Jones, T. P. \& Rowe, N. P. (eds) Fossil plants and spores: Modern techniques, 33-5. London: Geological Society of London.

Fairon-Demaret, M. \& Berry, C. M. 2000. A reconsideration of Hyenia elegans Kräusel \& Weyland and Hyenia 'complexa' Leclercq - two Middle Devonian cladoxylopsids from western Europe. International Journal of Plant Sciences 161, 473-94.

Fairon-Demaret M. \& Li, C.-S. 1993. Lorophyton goense gen. et sp. nov. from the Lower Givetian of Belgium and a discussion of the Middle Devonian Cladoxylopsida. Review of Palaeobotany and Palynology 77, 1-22.

Hilton J., Geng, B.-Y. \& Kenrick, P. 2003. A novel Late Devonian (Frasnian) woody Cladoxylopsid from China. International Journal of Plant Sciences 164, 793-805.

Kerp, H., Hass, H. \& Mosbrugger, V. 2001. New data on Nothia aphylla Lyon, 1964 ex El-Saadawy and Lacey, 1979, a poorly known plant from the Lower Devonian Rhynie Chert. In Gensel, P. G. \& Edwards, D. (eds) Plants invade the land: evolutionary and environmental perspectives, 52-82. New York: Columbia University Press.

Lang, W. H. 1927. Contributions to the study of the Old Red Sandstone Flora of Scotland. VII. On a specimen of Pseudosprochnus from the Stromness Beds. Transactions of the Royal Society of Edinburgh 55, 453-5 and Pl. 2, fig 32.
Leclercq, S. \& Andrews, H. N. 1960. Calamophyton bicephalum, a new species from the Middle Devonian of Belgium. Annals of the Missouri Botanical Garden 47, 1-23.

Long, A. G. 1976. Further observations on some Lower Carboniferous seeds and cupules. Transactions of the Royal Society of Edinburgh 69, 278-93.

Marshall, J. E. A. 1996. Rhabdosporites langii, Geminospora lemurata and Contagisporites optivus: an origin for heterospory within progymnosperms. Review of Palaeobotany and Palynology 93, 159-89.

Mykura, W. 1983. Old Red Sandstone. In Craig, G. Y. (ed.) The Geology of Scotland, 205-51. Edinburgh: Scottish Academic Press.

Peach, B. N. 1879. A list of fossil plants, collected in Shetland, by Messrs B. N. Peach and John Horne, of the Geological Survey, in 1878. Quarterly Journal of the Geological Society of London 35 , 811.

Rothwell, G. W. \& Serbet, R. 1994. Lignophyte phylogeny and the evolution of spermatophytes: a numerical cladistic analysis. Systematic Botany 19, 443-82.

Salter, J. W. 1857. On the remains of terrestrial plants in the old red Sandstone of Caithness. Quarterly Journal of the Geological Society of London 14, 72-8 and Pl. V.

Scott, A. C. 1990. Preservation, evolution and extinction of plants in Lower Carboniferous volcanic sequences in Scotland. Geological Society of America Special Paper 244, 25-38.

Schweitzer, H. J. 1972. Die Mitteldevonflora von lindlar (Rheinland). 2. Filicineae-Hyenia elegans Kraüsel \& Weiland. Palaeontographica Abh. B 137, 154-75.

Schweitzer, H. J. 1973. Die Mitteldevonflora von Lindar (Rheinland). 4. Filicineae-Calamophyton primaevum Kraüsel \& Weiland. Palaeontographica Abh. B 140, 117-50.

Seward, A. C. 1933. Plant life through the ages (2nd edn). Cambridge: Cambridge University Press.

Soria, A., Meyer-Berthaud, B. \& Scheckler, S.E. 2001. Reconstructing the architecture and growth habit of Pietzschia levis sp. nov. (Cladoxylopsida) from the Late Devonian of southeastern Morocco. International Journal of Plant Sciences 162, 911-26.

Stein, W. E. \& Hueber, F. M. 1989. The anatomy of Pseudosporochnus: P. hueberi from the Devonian of New York. Review of Palaeobotany and Palynology 60, 311-59.

Trewin, N. 1994. Depositional environment and preservation of biota in the Lower Devonian hot-springs of Rhynie, Aberdeenshire. Transactions of the Royal Society of Edinburgh: Earth Sciences $\mathbf{8 4}$ (for 1993), 433-42.

C. M. BERRY, School of Earth, Ocean and Planetary Sciences, Cardiff University, Main Building,

Park Place, Cardiff, CF10 3YE, Wales, UK.

J. HILTON, School of Geography, Earth and Environmental Sciences, University of Birmingham,

Edgbaston, Birmingham, B15 2TT, UK.

MS received 10 June 2005. Accepted for publication 1 August 2006. 